\title{
DIARE DAN PEMBERIAN ASI EKSKLUSIF PADA BAYI UMUR 0-6 BULAN
}

\author{
Marianawati Saragih, \& Yanita Listianasari \\ Staf Dosen Jurusan Gizi, Poltekkes Kemenkes Tasikmalaya
}

\begin{abstract}
Abstrak
Diare adalah suatu keadaan yang ditandai dengan bertambahnya frekuensi defekasi lebih dari tiga kali sehari yang disertai dengan perubahan konsistensi tinja menjadi lebih cair dengan/tanpa darah dan /tanpa lendir. Diare merupakan salah satu penyebab utama morbiditas dan mortalitas pada anak di Negara berkembang. Penelitian ini bertujuan untuk mengetahui hubungan pengetahuan ibu tentang diare dengan pemberian ASI eksklusif pada bayi umur 0-6 bulan. Jenis penelitian ini adalah kuantitatif dengan pendekatan studi potong lintang (cross sectional). Subjek penelitian ini adalah adalah seluruh ibu yang mempunyai bayi yang berusia 0-6 bulan yang terdaftar dan hadir pada saat posyandu di poskesdes wilayah kerja Puskesmas Cilimus Kabupaten Kuningan. Metode pengambilan sampel dengan purposive sampling sebanyak 70 responden. Uji analisis pada penelitian ini adalah dengan uji chi square. Hasil uji statistik menunjukkan sebagian besar responden adalah ibu dengan kelompok umur 19-30 tahun, tingkat pendidikan SMA, pekerjaan ibu rumah tangga dan pengetahuan tentang diare baik. Hasil penelitian menunjukkan bahwa tidak ada hubungan yang signifikan antara pengetahuan ibu tentang diare dengan pemberian ASI eksklusif pada bayi umur 0-6. Penyuluhan tentang ASI sebaiknya dilakukan secara berkala agar dapat meningkatkan pengetahuan ibu mengenai pemberian ASI eksklusif kepada bayinya.
\end{abstract}

Kata Kunci : Pengetahuan ibu tentang diare, ASI eksklusif.

\begin{abstract}
Diarrhea is a condition characterized with the increasing frequency of defecation more than three times a day followed with the change of feces consistency into more liquid with /without blood and with /without mucous. Diarrhea is one main cause of morbidity and mortality in children in developing countries. This research aimed to find out the relationship between mother's nutrition about diarrhea and exclusive breastfeeding in 0-6 month age baby. This research was quantitative one with cross-sectional approach. The subject of research was all mothers with 0-6 month babies enlisted and present during posyandu (integrated service post) in poskesdes (village health post) in work area of Puskesmas Cilimus of Kuningan Regency. The sampling method used was Purposive Sampling one, obtaining 70 respondents as the sample. Data analysis was conducted using Chi Square test. The result of statistic test showed that most respondents were mothers aged 19-30 years, with education level of Senior High School, housewives and with good knowledge on diarrhea. There was no significant relationship between mother's knowledge on diarrhea and Exclusive breastfeeding. It could be concluded that There was no significant relationship between mother's knowledge on diarrhea and Exclusive Breastfeeding in 0-6 month babies. Counseling about breastfeeding should be carried out periodically so as to increase the mother's knowledge regarding exclusive breastfeeding to her baby.
\end{abstract}

Keywords: mother's knowledge on diarrhea, exclusive breastfeeding

\section{PENDAHULUAN}

Diare adalah suatu keadaan yang ditandai dengan bertambahnya frekuensi defekasi lebih dari tiga kali sehari yang disertai dengan perubahan konsistensi tinja menjadi lebih cair dengan /tanpa darah dan dengan /tanpa lender (Rosari, Rini, dan Masrul, 2013). Diare merupakan salah satu penyebab utama morbiditas dan mortalitas pada anak di Negara berkembang (WHO, 2009). 
Menurut data United Nations Children's Fund (UNICEF) dan World Health Organization (WHO) pada tahun 2009, diare merupakan penyebab kematian nomor 2 pada balita di dunia, nomor 3 pada bayi dan nomor 5 bagi segala umur. Data UNICEF memberitakan bahwa 1,5 juta anak meninggal dunia setiap tahunnya karena diare. Di beberapa negara berkembang hanya $39 \%$ penderita mendapatkan penanganan yang serius. Di Indonesia, sebanyak 162 ribu balita meninggal setiap tahun atau sekitar 460 balita setiap harinya akibat diare. Daerah Jawa Barat merupakan salah satu yang tertinggi, di mana kasus kematian akibat diare banyak menimpa anak berusia di bawah 5 tahun. Kejadian diare pada bayi dapat disebabkan karena kesalahan dalam pemberian makan, dimana bayi sudah diberi makan selain Air Susu Ibu (ASI) sebelum berusia 4 bulan (Qauliyah, 2010).

ASI merupakan makanan terbaik bagi bayi karena mengandung semua zat gizi dalam jumlah dan komposisi yang ideal yang dibutuhkan oleh bayi untuk tumbuh dan berkembang secara optimal, terutama pada umur 0 sampai 6 bulan. Pemberian ASI eksklusif kepada bayi umur 0-6 bulan sangat dianjurkan dan memberikan makanan pendamping ASI secara benar setelah itu sampai bayi /anak berumur 2 tahun(Sartono, dan Utaminingrum, 2012). ASI eksklusif adalah pemberian hanya ASI saja tanpa cairan atau makanan padat apapun kecuali vitamin, mineral, atau obat dalam bentuk tetes atau sirup sampai usia 6 bulan (Rahmadhani, Lubis, dan Edison, 2013).

Dari data Balai Pengobatan Desa, Posyandu dan Puskesmas Cilimus, diketahui jumlah penderita diare pada bayi tahun 2009 sebanyak 132 bayi (20,82\%) dan tahun 2010 sebanyak 133 bayi $(20,56 \%)$. Pada tahun 2010 penyakit diare menempati urutan ke sepuluh penyebab utama bagi masyarakat yang berkunjung ke puskesmas. Melalui program penanggulangan diare jumlah kasus diare memang selalu ada dan tidak pernah sampai terjadi potensi Kejadian Luar Biasa (KLB) di wilayah kerja Puskesmas Cilimus.

Data hasil pemantauan ASI Eksklusif bulan April 2011 di Puskesmas Cilimus, sebesar $54 \%$ ibu sudah memberikan ASI eksklusif kepada bayinya, tetapi belum sesuai dengan standar pencapaian nasional yaitu sebesar $80 \%$. Hasil wawancara dengan bagian gizi Puskesmas Cilimus Kabupaten Kuningan, rata-rata di masyarakat Cilimus masih kurang dalam memperhatikan pemberian ASI eksklusif oleh ibu kepada bayinya. Penelitian ini bertujuan untuk memberikan informasi lebih lanjut mengenai Hubungan Pengetahuan tentang Diare dengan pemberian ASI Eksklusif pada Bayi Umur 0-6 Bulan.

\section{METODE PENELITIAN}

Desain penelitian adalah cross sectional yang bersifat observasi. Populasi penelitian adalah seluruh ibu yang mempunyai bayi berumur 0-6 bulan yang terdaftar dan hadir pada saat posyandu. Sampel sebanyak 70 orang yang diambil menggunakan teknik purposive sampling, dengan kriteria, antara lain ibu yang mempunyai bayi umur 0-6 bulan, tercatat dan hadir dalam registrasi posyandu, status gizi bayi baik, bayi tidak mengalami intoleransi laktosa, bersedia menjadi responden.

Data yang dikumpulkan meliputi karakteristik ibu (umur, tingkat pendidikan, jenis pekerjaan), karakteristik bayi (umur) dan pengetahuan ibu tentang diare. Data tersebut diperoleh dengan menyebarkan kuesioner yang berisi beberapa kriteria yang harus ditanggapi atau diisi oleh responden penelitian. Tingkat pengetahuan responden terdiri dari 7 item pertanyaan. Bila jawaban benar lebih dari $75 \%$ dianggap baik, bila 
jawaban benar $60-75 \%$ dianggap cukup dan bila jawaban benar kurang dari $60 \%$ dianggap kurang. Pemberian ASI ekslusif dan tidak ekslusif pada bayi terdiri dari 12 item pertanyaan dengan memberikan jawaban ya atau tidak.

Tahapan analisis data meliputi analisis univariat, yaitu: umur ibu, umur bayi, tingkat pendidikan ibu, jenis pekerjaan ibu, pengetahuan ibu tentang diare. Analisis bivariat, yaitu pengetahuan ibu tentang diare dengan pemberian ASI Eksklusif. Uji statistik yang digunakan adalah chi-square.

\section{HASIL PENELITIAN}

Tabel 1. Distribusi Karakteristik Ibu berdasarkan Kelompok Umur

\begin{tabular}{cccc}
\hline No. & $\begin{array}{c}\text { Umur } \\
\text { (Tahun) }\end{array}$ & Frekuensi & $\begin{array}{c}\text { Prosentase } \\
\text { (\%) }\end{array}$ \\
\hline 1 & $19-30$ th & 48 & 68,57 \\
\hline 2 & $31-40$ th & 21 & 30 \\
\hline 3 & $41-50$ th & 1 & 1,43 \\
\hline & Jumlah & 70 & 100 \\
\hline
\end{tabular}

Dari tabel 1 diketahui bahwa sebagian besar ibu berumur 19-30 tahun yaitu berjumlah 48 orang dengan prosentase $68,57 \%$ dan ibu yang berumur $31-40$ tahun berjumlah 21 orang dengan prosentase $30 \%$ serta ibu berumur 41-50 tahun berjumlah 1 orang dengan prosentase $1,43 \%$.

Tabel 2. Distribusi Karakteristik Bayi Berdasarkan Umur

\begin{tabular}{cccc}
\hline No & $\begin{array}{c}\text { Umur } \\
\text { (Bulan) }\end{array}$ & Frekuensi & $\begin{array}{c}\text { Prosentase } \\
(\%)\end{array}$ \\
\hline 1 & 1 & 5 & 7,14 \\
\hline 2 & 2 & 14 & 20 \\
\hline 3 & 3 & 20 & 28,58 \\
\hline 4 & 4 & 12 & 17,14 \\
\hline 5 & 5 & 7 & 10 \\
\hline 6 & 6 & 12 & 17,14 \\
\hline & Jumlah & 70 & 100 \\
\hline
\end{tabular}

Dari tabel 2 diketahui bahwa karakteristik bayi menurut umur yaitu bayi yang berumur 1 bulan berjumlah 5 orang dengan prosentase $7,14 \%$, bayi yang berumur 2 bulan berjumlah 14 orang dengan prosentase $20 \%$, bayi yang berumur 3 bulan berjumlah 20 orang dengan prosentase $28,58 \%$, bayi yang berumur 4 bulan berjumlah 12 orang dengan prosentase $17,14 \%$, bayi yang berumur 5 bulan berjumlah 7 orang dengan prosentase $10 \%$ dan bayi yang berumur 6 bulan berjumlah 12 orang dengan prosentase $17,14 \%$.

Tabel 3. Distribusi Karakteristik Ibu berdasarkan Tingkat Pendidikan

\begin{tabular}{llcc}
\hline No & $\begin{array}{c}\text { Tingkat } \\
\text { Pendidikan }\end{array}$ & Frekuensi & $\begin{array}{c}\text { Prosentase } \\
\text { (\%) }\end{array}$ \\
\hline 1 & SD & 13 & 18,57 \\
\hline 2 & SMP & 24 & 34,29 \\
\hline 3 & SMA & 27 & 38,57 \\
\hline 4 & Diploma & 4 & 5,71 \\
\hline 5 & Sarjana & 2 & 2,86 \\
\hline & Jumlah & 70 & 100 \\
\hline
\end{tabular}

Dari tabel 3 diketahui bahwa karakteristik ibu berdasarkan tingkat pendidikan yaitu tidak tamat SD tidak ada, tamat SD berjumlah 13 orang dengan prosentase $18,57 \%$, tamat SMP berjumlah 24 orang dengan prosentase $34,29 \%$, tamat SMA berjumlah 27 orang dengan prosentase $38,57 \%$, Diploma berjumlah 4 orang dengan prosentase $5,71 \%$ dan Sarjana berjumlah 2 orang dengan prosentase $2,86 \%$.

Pada tabel 4 dapat dilihat bahwa karakteristik ibu berdasarkan jenis pekerjaan, sebagian besar pekerjaan ibu adalah ibu rumah tangga berjumlah 64 orang dengan prosentase 91,43\%, Wiraswasta berjumlah 4 orang dengan prosentase $5,71 \%$, PNS berjumlah 1 orang dengan prosentase $1,43 \%$ dan Buruh 
berjumlah 1 orang dengan prosentase $1,43 \%$ serta petani tidak ada.

Tabel 4. Distribusi Karakteristik lbu berdasarkan Jenis Pekerjaan

\begin{tabular}{clcc}
\hline No & $\begin{array}{c}\text { Jenis } \\
\text { Pekerjaan }\end{array}$ & Frekuensi & $\begin{array}{c}\text { Prosentase } \\
\text { (\%) }\end{array}$ \\
\hline 1 & PNS & 1 & 1,43 \\
\hline 2 & Wiraswasta & 4 & 5,71 \\
\hline 3 & Buruh & 1 & 1,43 \\
\hline 4 & Petani & 0 & 0 \\
\hline 5 & $\begin{array}{l}\text { lbu Rumah } \\
\text { Tangga }\end{array}$ & 64 & 91,43 \\
\hline & Jumlah & 70 & 100 \\
\hline
\end{tabular}

Dari tabel 5 diketahui bahwa karakteristik ibu berdasarkan pengetahuan ibu tentang diare yaitu sebagian besar pengetahuan ibu tentang diare baik yaitu berjumlah 39 orang dengan prosentase $55,71 \%$, pengetahuan ibu tentang diare cukup berjumlah 10 orang dengan prosentase $14,29 \%$ dan pengetahuan ibu tentang diare kurang berjumlah 21 dengan prosentase $30 \%$.

Tabel 5. Distribusi Ibu berdasarkan Pengetahuan tentang Diare

\begin{tabular}{clcc}
\hline No & $\begin{array}{l}\text { Pengetahuan } \\
\text { tentang Diare }\end{array}$ & Frekuensi & $\begin{array}{c}\text { Prosentase } \\
\text { (\%) }\end{array}$ \\
\hline 1 & Baik & 39 & 55,71 \\
\hline 2 & Cukup & 10 & 14,29 \\
\hline 3 & Rendah & 21 & 30 \\
\hline & Jumlah & 70 & 100 \\
\hline
\end{tabular}

Pada tabel 6 diketahui bahwa ibu dengan pengetahuan tentang diare baik berjumlah 23 orang yang memberi ASI eksklusif kepada bayinya dan 16 orang tidak memberikan ASI eksklusif kepada bayinya, ibu dengan pengetahuan tentang diare cukup berjumlah 6 orang yang memberikan ASI eksklusif kepada bayinya dan 4 orang tidak memberikan ASI eksklusif kepada bayinya, ibu dengan pengetahuan rendah berjumlah 13 orang yang memberikan ASI eksklusif kepada bayinya dan 8 orang tidak memberikan ASI eksklusif kepada bayinya.

Tabel 6. Pengetahuan lbu tentang Diare dengan Pemberian ASI Eksklusif

\begin{tabular}{lccc}
\hline \multirow{2}{*}{$\begin{array}{c}\text { Tingkat } \\
\text { Pengetahuan }\end{array}$} & \multicolumn{3}{c}{ ASI } \\
\cline { 2 - 3 } & Eksklusif & $\begin{array}{c}\text { Non } \\
\text { Eksklusif }\end{array}$ & \\
\hline Baik & 23 & 16 & 39 \\
\hline Cukup & 6 & 4 & 10 \\
\hline Kurang & 13 & 8 & 21 \\
\hline Jumlah & 42 & 28 & 70 \\
\hline$\rho=0,976$ & & &
\end{tabular}

Dari perhitungan dengan menggunakan uji chi square menghasilkan $p>0,05$ dengan nilai signifikasi 0,976 yang berarti tidak ada hubungan yang signifikan atau tidak bermakna. Hal ini menunjukkan tidak adanya hubungan antara pengetahuan ibu tentang diare dengan pemberian ASI eksklusif.

\section{PEMBAHASAN}

Berdasarkan distribusi umur ibu sebagian besar ibu berumur 19-30 tahun dengan prosentase $68,57 \%$. Umur tersebut merupakan kelompok reproduktif yang paling ideal dari aspek kesehatan. Bila ditinjau dari tugas dan perkembangan manusia maka usia tersebut adalah masa dewasa awal yang merupakan usia reproduksi. Menurut Destaria (2011), usia produktif yang optimal untuk reproduksi sehat adalah antara 20-25 tahun. Risiko akan meningkat pada usia dibawah 20 tahun maupun di atas 35 tahun. Wanita hamil pada usia muda akan memiliki beberapa risiko, antara lain keguguran, persalinan prematur, BBLR, kelainan bawaan, mudah terjadi infeksi, anemia pada kehamilan, keracunan kehamilan dan kematian (Destaria, 2011). 
Karakteristik bayi menurut umur yang paling tinggi prosentasenya pada umur 3 bulan yaitu $28,58 \%$. Menurut Lestari, dkk (2013) sumber nutrisi alamiah bagi bayi yang memiliki kandungan gizi cukup dan merupakan makanan yang paling sempurna adalah ASI. ASI saja diberikan sampai bayi berusia 6 bulan, tanpa tambahan cairan ataupun makanan lain selain ASI (Lestari, Zuraida, dan Larasati, 2013).

$$
\text { Rahmadhani, dkk }
$$
menyebutkan bahwa bayi yang mendapatkan ASI lebih jarang terkena diare karena adanya zat protektif saluran cerna seperti Lactobacillus bifidus, laktoferin, lisozim, SlgA, faktor alergi serta limfosit $T$ dan B. Zat protektif ini berfungsi untuk daya tahan tubuh terhadap benda asing yang masuk ke dalam tubuh (Rahmadhani, Lubis, dan Edison, 2013).

Berdasarkan distribusi tingkat pendidikan ibu sebagian besar ibu dengan tingkat pendidikan SMA dengan prosentase $38,57 \%$. Tingkat pendidikan ibu merupakan salah satu faktor yang mempengaruhi pemberian ASI eksklusif. Pendidikan pada satu sisi mempunyai dampak positif yaitu ibu mengerti akan pentingnya pemeliharaan kesehatan termasuk pemberian ASI ekslusif. Namun pendidikan yang semakin tinggi juga akan berdampak adanya perubahan nilai sosial seperti anggapan bahwa menyusui dianggap tidak modern dan dapat mempengaruhi payudara itu. Pemberian ASI pada bayi dianggap tidak modern dan menempatkan ibu pada kedudukan lebih rendah dibandingkan dengan ibu golongan atas (Nilakesuma, Jurnalis, dan Rusjdi, 2015).

Berdasarkan jenis pekerjaan dapat diketahui sebagian besar ibu tidak bekerja atau mempunyai status sebagai Ibu rumah tangga dengan prosentase sebesar $91,43 \%$. Hal ini mempunyai kemungkinan bahwa ibu yang tidak bekerja akan lebih banyak kesempatan untuk memberikan ASI secara eksklusif dibandingkan dengan ibu yang bekerja. Menurut Dahlan dkk (2013), apabila status pekerjaan ibu bekerja, maka besar kemungkinan ibu tidak memberikan ASI eksklusif pada bayinya. Apabila status pekerjaan ibu tidak bekerja maka besar kemungkinan ibu dapat memberikan ASI eksklusifnya. Kebanyakan ibu bekerja, waktu merawat bayinya lebih sedikit, sehingga memungkinkan ibu tidak memberikan ASI eksklusif pada bayinya.

lbu yang bekerja menyebabkan terjadinya resiko menyusui secara non eksklusif. lbu yang bekerja formal mempunyai kecendurungan untuk memberikan pengganti ASI karena waktu merawat bayinya lebih sedikit. Wanita yang bekerja di rumah dapat mengatur waktunya dan setiap saat bila diperlukan dapat menghentikan pekerjaannya untuk meluangkan waktu guna menyusui bayinya. Lain halnya dengan wanita yang bekerja dengan cara harus meninggalkan rumah, mereka ini tidak memiliki waktu yang terlalu banyak dibanding wanita yang tidak bekerja sehingga untuk memberikan pada bayinya terbatas. Ketidakhadiran ibu di rumah untuk jangka waktu tertentu karena bekerja biasanya akan menimbulkan masalah dalam mengatur waktu untuk memberikan ASI pada bayinya (Dahlan, Mubin, Mustika, 2013).

Berdasarkan pengetahuan ibu tentang diare diketahui sebagian besar ibu mempunyai pengetahuan yang baik tentang diare dengan prosentase $55,71 \%$. Masih banyaknya pengetahuan ibu tentang penyakit diare yang kurang yaitu sebesar $30 \%$ dimungkinkan karena tingkat pendidikan responden yang SMP masih relatif besar yaitu dengan prosentase $34,29 \%$ dan SD $18,57 \%$.

Menurut Notoatmodjo (2003) bahwa semakin tinggi pendidikan maka ia akan mudah menerima hal baru dan akan mudah menyesuaikan dengan hal baru tersebut, 
sehingga dengan tingkat pendidikan yang tinggi maka tingkat pengetahuan akan tinggi juga. Pengetahuan sangat erat kaitannya dengan pendidikan, dimana diharapkan seseorang dengan pendidikan tinggi, pengetahuannya akan semakin luas. Namun perlu ditekankan bahwa seseorang yang berpendidikan rendah tidak berarti mutlak berpengetahuan rendah pula. Peningkatan pengetahuan tidak mutlak diperoleh di pendidikan formal, akan tetapi juga dapat diperoleh pada pendidikan nonformal. Faktor berikutnya yang dapat mencegah terjadinya diare pada bayi yaitu kebersihan dalam menyiapkan makanan atau minuman yang diberikan pada bayi dapat terjaga dengan baik, sehingga kemungkinan bakteri untuk dapat masuk ke dalam tubuh bayi menjadi lebih kecil bila dibandingkan bayi yang mendapatkan makanan dengan kebersihan dalam persiapan makanan kurang .

\section{KESIMPULAN}

Hasil penelitian menunjukkan tidak adanya hubungan antara pengetahuan ibu tentang diare dengan pemberian ASI eksklusif.

Ibu harus tetap berusaha memberikan ASI eksklusif sampai bayi berumur 6 bulan. Penyuluhan tentang ASI sebaiknya dilakukan secara berkala agar dapat meningkatkan pemberian ASI eksklusif oleh ibu kepada bayinya sebagai upaya untuk menurunkan risiko terjadinya penyakit diare.

\section{DAFTAR PUSTAKA}

Dahlan, A., Mubin, F., Mustika, D.N., (2013). Hubungan Status Pekerjaan dengan Pemberian ASI eksklusif di Kelurahan Palebon Kecamatan Pedurungan Kota Semarang. Jurnal Kebidanan Universitas Muhammadiyah Semarang, 1(1): 1-5.

Destaria, S., (2011). Perbandingan Luaran Maternal dan Perinatal Kehamilan Trimester Ketiga antara Usia Muda dan Usia Reproduksi. Skripsi: Universitas Diponegoro.

Lestari, D., Zuraida, R dan Larasati, (2013). Hubungan Tingkat Pengetahuan Ibu tentang Air Susu Ibu dan Pekerjaan Ibu dengan Pemberian ASI Eksklusif di Kelurahan Fajar Bulan. Medical Journal of Lampung University. 2(4): 88-99.

Nilakesuma, A., Jurnalis, Y.D dan Rusjdi, S.R., (2015). Hubungan Status Gizi Bayi dengan Pemberian ASI Eksklusif, Tingkat Pendidikan Ibu dan Status Ekonomi Keluarga di Wilayah Kerja Puskesmas Padang Pasir. JURNAL Kesehatan Andalas, 4(1): 37-44.

Notoatmodjo, (2003). IImu Kesehatan Masyarakat. Jakarta: Rineka Cipta.

Qauliyah, A., (2010). Patofisiologi, Gejala Klinik dan Penatalaksanaan Diare. diunduh tgl. 30 Juli 2017 dari http://astaqauliyah.com

Rahmadhani, E.P., Lubis, G., dan Edison (2013). Hubungan Pemberian ASI eksklusif dengan Angka Kejadian Diare Akut pada Bayi Usia 0-1 Tahun di Puskesmas Kuranji Kota Padang. Jurnal Kesehatan Andalas, 2(2): 62-66.

Rosari, A., Rini, E.A dan Masrul, (2013). Hubungan Diare dengan Status Gizi Balita di Kelurahan Lubuk Buaya Kecamatan Koto Tangah Kota Padang. Jurnal Kesehatan Andalas, 2(3): 111115.

Sartono, A dan Utaminingrum, H. (2012). Hubungan Pengetahun Ibu, Pendidikan Ibu dan Dukungan Suami dengan Praktek Pemberian ASI Eksklusif di Kelurahan Muktiharjo Kidul Kecamatan Telogosari Kota Semarang. Jurnal Gizi Universitas Muhammadiyah Semarang, 1(1): 1-9.

WHO, (2009). Diarrhoeal disease. Diunduh tgl. 30 Juli 2017 dari http://www.who. intmediacentre/factsheets/fs330/en/inde x.html. 